\title{
COVID-19 in China: From epidemiology to treatment (Review)
}

\author{
HONGTAO CHEN $^{1,2}$, SHIPIN WU ${ }^{1}$ and XIAOYONG ZHANG ${ }^{3}$ \\ ${ }^{1}$ Department of Infectious Diseases, The Second Clinical Medical College, Shenzhen People's Hospital, \\ Jinan University; ${ }^{2}$ Key Laboratory of Pathogenic Microorganisms of Shenzhen, Shenzhen Institute of \\ Respiratory Diseases, Shenzhen, Guangdong 518020; ${ }^{3}$ State Key Laboratory of Organ Failure Research, \\ Guangdong Provincial Key Laboratory of Viral Hepatitis Research, Department of Infectious Diseases, \\ Nanfang Hospital, Southern Medical University, Guangzhou, Guangdong 510515, P.R. China
}

Received April 11, 2020; Accepted August 28, 2020

DOI: $10.3892 /$ etm.2020.9353

\begin{abstract}
Coronavirus disease 2019 (COVID-19) is a newly emerging infectious disease caused by the novel coronavirus SARS-CoV-2. It first became prevalent in Wuhan, Hubei, China in December 2019. COVID-19 was initially characterized by pneumonia of unknown etiology, accompanied by fever, dry cough and fatigue. Due to its highly infectious nature it rapidly led to widespread human infection, causing 80,924 confirmed cases and 3,140 mortalities in mainland China as of March 9, 2020. The present review highlights the prevalence of COVID-19 in China, the etiology, pathology, clinical presentation, laboratory and chest imaging tests, and treatment of this disease.
\end{abstract}

\section{Contents}

1. Introduction

2. Epidemiology

3. Etiology

4. Pathogenesis

5. Pathology

6. Clinical characteristics

7. Laboratory and chest imaging tests

8. Treatment

9. Conclusion

Correspondence to: Professor Xiaoyong Zhang, State Key Laboratory of Organ Failure Research, Guangdong Provincial Key Laboratory of Viral Hepatitis Research, Department of Infectious Diseases, Nanfang Hospital, Southern Medical University, 1838 North Guangzhou Avenue, Guangzhou, Guangdong 510515, P.R. China

E-mail: xiaoyzhang@smu.edu.cn

Key words: COVID-19, coronavirus, epidemiology, pathology, treatment

\section{Introduction}

From December 29, 2019, when cluster cases of pneumonia with unknown etiology (PUE) were first reported in Wuhan, the capital of Hubei, China, the disease spread rapidly across the city (1). On January 3,2019, researchers at the National Institute for Viral Disease Control and Prevention (Beijing, China) combined the use of Sanger sequencing, Illumina sequencing and nanopore sequencing on bronchoalveolar lavage (BAL) fluid samples from a patient with PUE from Wuhan to analyze the pathogen genome (2). A new $\beta$ genus coronavirus was identified for the first time and named 2019 novel coronavirus (2019-nCoV) (3). On February 11, 2020, the international committee on taxonomy of viruses designated this novel discovery as a severe acute respiratory syndrome coronavirus 2 (SARS-CoV-2) (4). On the same day, the World Health Organization (WHO) coined the name 'COVID-19,' meaning coronavirus disease 2019 (5). The present review highlights the epidemiology, etiology, pathobiology, clinical manifestations and treatment of COVID-19.

\section{Epidemiology}

The initial four cases of PUE, with clinical manifestations resembling viral pneumonia, were reported via the domestic PUE surveillance system (6) on December 29, 2020, in Wuhan, Hubei, China (1). At the end of December 2019, the number of reported cases escalated to 27 (7). In late December 2019, several patient BAL samples were sent to sequencing companies for next-generation sequencing (NGS) analysis and the results suggested a type of coronavirus. On December 31, 2019, the China National Health Commission (NHC) sent a team of experts to Wuhan to perform the epidemiological investigation (8). The complete genome sequence of the novel coronavirus was determined by researchers from the Wuhan Institute of Virology, Chinese Academy of Sciences, China (3). On January 5, 2020, the virus was isolated, and further phylogenetic analysis of the sequencing data confirmed the novel coronavirus is a new $\beta$ genus coronavirus $(2,8)$. The first reported mortality from the virus occurred on January 9 , 2020 (7). On January 11, 2020, a 69-year-old brain surgery patient who had no respiratory symptoms prior to surgery developed symptoms of fever and was confirmed to have novel 
coronavirus pneumonia (NCP) (9). He subsequently infected one doctor and 13 nurses in Wuhan Union hospital, which was the first direct evidence of human-to-human transmission. On the same day, Professor Zhang Yongzhen's team from Fudan University in Shanghai first shared the sequence of the new coronavirus genome on the Virological (https://virological. org) and GenBank (https://www.ncbi.nlm.nih.gov) websites. As the reported number of cases from other provinces besides Hubei continued to rise, on January 23, 2020, Wuhan city was locked down by the local government to prevent the disease from spreading. At the end of January 2020, 11,821 patients were confirmed to be infected with COVID-19 worldwide, and there were 3,215 cases in Wuhan (10). The government renovated and built 86 designated hospitals and 16 mobile cabin hospitals and provided more than 60,000 beds to effectively facilitate the admission and treatment of several confirmed patients as soon as possible in Wuhan (11). In addition, the government focused research on detection reagents, and several nucleic acid detection reagents, such as the BGI Group 2019-nCOV Nucleic Acid Detection Kit, were approved for clinical application, which improved the screening of suspected cases. Since strict joint prevention and control measures were taken by the government, the outbreak of the disease was rapidly restrained. The chronological incidence of confirmed COVID-19 cases and COVID-19-associated mortalities are presented in Fig. 1A-D. As of March 9, 2020, 80,924 cases have been confirmed in mainland China, with 3,140 mortalities (10). A total of $84 \%$ of cases were in Hubei and Wuhan was the worst-hit area in Hubei (Fig. 2). The case fatality rate is $3.88 \%(3,140 / 80,924)$ worldwide, with $4.46 \%(3,024 / 67,760)$ in Hubei and $4.81 \%(2,404 / 49,965)$ in Wuhan (10).

\section{Etiology}

Early virus sequencing analysis of BAL samples from five patients demonstrated that the genomes among these isolates were almost identical, with 99.8-99.9\% sequence identity (12). In another study, virus sequencing was performed on BAL and pharyngeal swab samples from nine patients, with $99.98 \%$ nucleotide identity (1). Further phylogenetic analysis of the virus indicated that it belonged to the $\beta$ genus coronavirus (3). Its genome sequence was dissimilar to the middle east respiratory syndrome coronavirus (MERS-CoV), (51.8\% identity) and SARS-CoV (79\% identity) and was closely associated with the bat SARS-like coronavirus RaTG13 (96.2\% identity) obtained from Rhinolophus affinis (3). Despite significant differences in genome sequences, the SARS-CoV-2 spike (S)-protein and SARS-CoV S-protein share an almost identical 3D structure in the receptor binding domain (RBD), suggesting that they have the same S-protein-angiotensin-converting enzyme 2 (ACE2) binding pathway (13). In addition, in vitro experiments have demonstrated that SARS-CoV-2 infects permissive cells via ACE2 on the cell membrane (3,14-17).

The mechanism of transfer of the virus from its natural hosts to other animals and humans remains unclear. With regards to the search for reservoir hosts, a study proposed that a species of snake may serve as the SARS-CoV-2 reservoir, based on sequence analysis and relative synonymous codon usage bias (18). An additional study suggested that pangolins were the probable animal source of SARS-CoV-2 (19). Although reservoir hosts are yet to be determined, these findings suggest the importance of harmonious coexistence between humans and wildlife. Recently, viral mutations during the epidemic have attracted interest. A study analyzed 103 SARS-CoV-2 genomes and demonstrated that these viruses evolved into two major types (L type and S type) (20). The $\mathrm{S}$ type is an ancestral and less aggressive type, which is less prevalent in Wuhan (Wuhan vs. the rest of the world, $3.7 \%$ vs. 38.4\%) (20). Conversely, the $\mathrm{L}$ type has evolved from the $\mathrm{S}$ type, has a higher transmission rate compared with the $\mathrm{S}$ type and is highly prevalent in Wuhan (Wuhan vs. the rest of the world, 96.3 vs. $61.6 \%$ ) (20). Analysis suggests that government intervention may have prevented the L type from spreading outwards (20). However, based on existing knowledge of coronaviruses, this new RNA virus may still mutate and recombine in the future, during which the virulence may be enhanced or weakened.

\section{Pathogenesis}

SARS-CoV-2 acts via ACE-2 on the surface of host cells (14-17). ACE-2 is predominantly expressed on type II alveolar cells in the lungs, and is also expressed in the heart, kidneys, endothelium and intestine (21). Following infection of ACE-2 expressing cells in the respiratory tract, including epithelial, alveolar epithelial and vascular endothelial cells and macrophages in the lungs, macrophages are activated by the pathogen-associated molecular patterns (PAMPs) derived from the virus and damage-associated molecular patterns (DAMPs), including ATP and DNA, which are generated following damage of the infected cells (22). Macrophage activation is generally considered a primary response to viral infection (23). Macrophages secrete interleukin (IL)-6 and IL-1 $\beta$ to recruit neutrophils and Tymphocytes into the lungs (23). In mild or moderate cases, recruited cells clear the infection, the immune response wanes and the patients recover. However, in severe or critical patients, a dysregulated immune response causes hyperinflammatory conditions and a cytokine storm (22).

The major immune characteristics in patients with severe COVID-19 are as follows:

i) hyperinflammatory conditions and cytokine storm. IL-6, secreted by monocytes, macrophages and dendritic cells (DCs) has been reported to be a key driver of inflammatory cytokine storms in patients with SARS-CoV or MERS-CoV (24,25). Elevated IL-6 serum levels have also been exhibited in patients with COVID-19 and are associated with acute respiratory distress syndrome (ARDS), respiratory failure and adverse clinical outcomes, including death (26). IL-6 has notable proinflammatory characteristics. It acts on lymphocytes via cis signaling to promote $\mathrm{T}$ helper 17 cell (Th17) and $\mathrm{T}$ follicular helper cell ( $\mathrm{Tfh}$ ) differentiation, enhances $\mathrm{CD}^{+} \mathrm{T}$ cytotoxic activity, and promotes B-cell differentiation and proliferation (26). IL-6 also acts on vascular endothelial cells via trans signaling to induce vascular endothelial growth factor (VEGF) expression and decrease E-cadherin expression on endothelial cells, resulting in increased vascular permeability and leakage (26). It also induces monocyte chemoattractant protein-1 (MCP-1) and IL-8 expression, to recruit monocytes and neutrophils into diseased tissues (26). Granulocyte-macrophage 

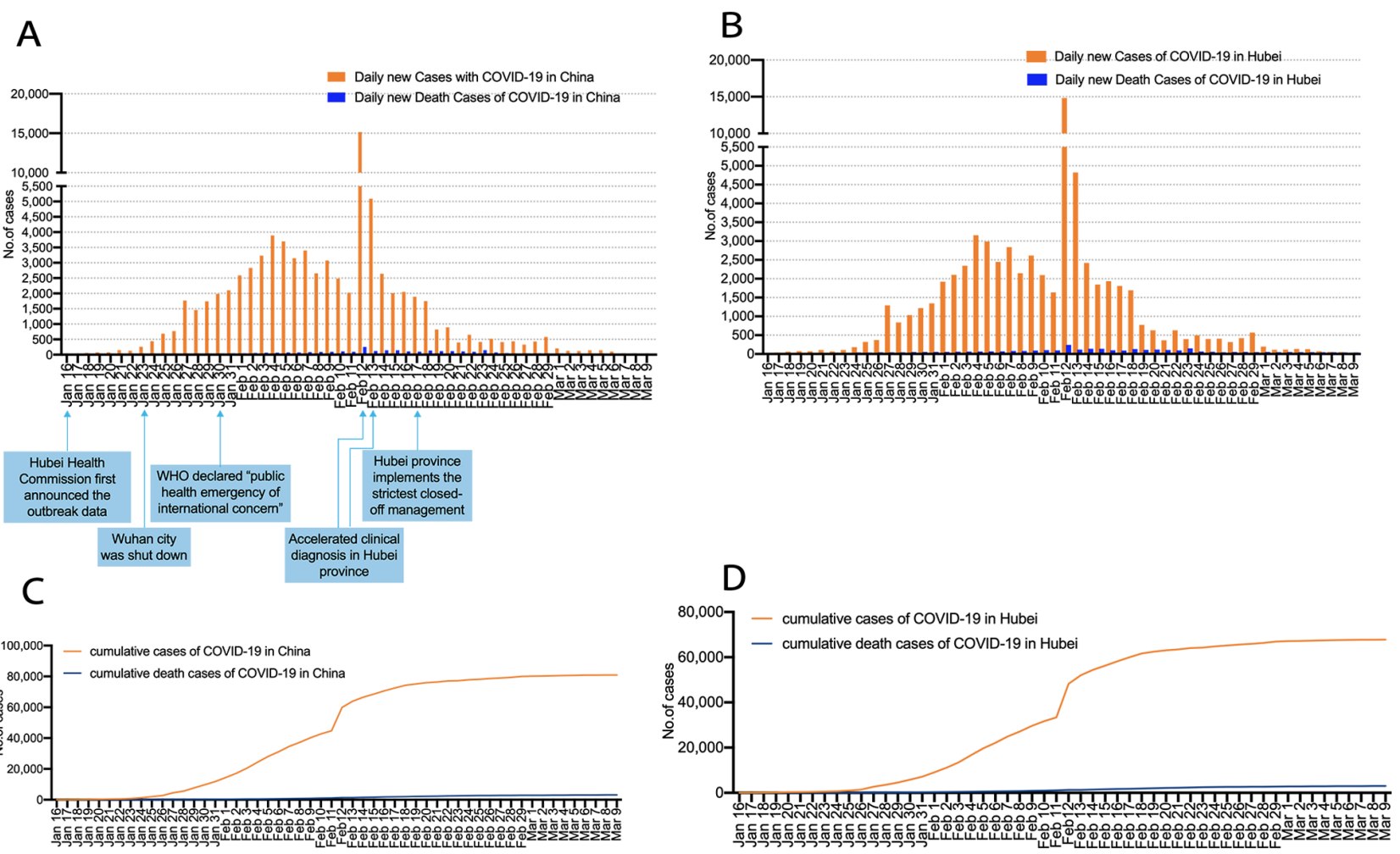

Figure 1. Chronological incidence of confirmed COVID-19 cases and mortalities in mainland China and Hubei province 2020. Daily new cases and new death cases of COVID-19 in China (A). Daily new cases and new death cases of COVID-19 in Hubei province (B). Cumulative confirmed cases and death cases of COVID-19 by date in China (C). Cumulative confirmed cases and death cases of COVID-19 by date in Hubei province (D). On January 16, 2020, Hubei Health Commission first announced 45 confirmed cases of COVID-19 and 2 mortalities (10). As of March 9, 2020, China had reported 80,924 confirmed cases of COVID-19 and 3,140 mortalities (10).

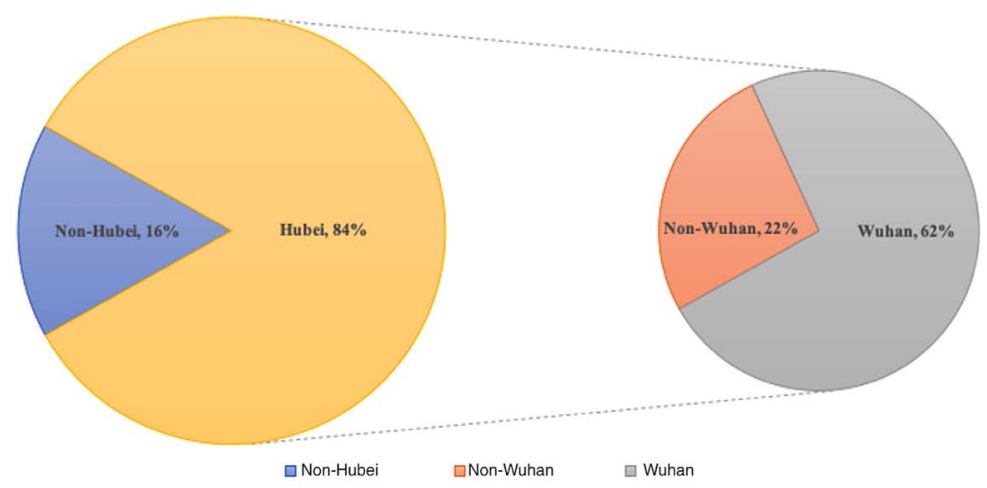

Figure 2. Geographical distribution of COVID-19 cases in mainland China. In mainland China, most cases were concentrated in Hubei province and Wuhan was the worst-hit city in Hubei (10).

colony-stimulating factor (GM-CSF) is another important cytokine in COVID-19 (27-29). CD4 ${ }^{+} \mathrm{T}$ lymphocytes activated by SARS-COV-2 become pathogenic T helper (Th) 1 cells and serve as a source of GM-CSF (27). GM-CSF activates mature myeloid cells to a proinflammatory phenotype, with enhanced cytokine and chemokine secretory capacity (28). Thus, GM-CSF is considered a primary communication conduit between inflammatory lymphocytes and myeloid cells (28). Patients with COVID-19 have been reported to have increased plasma concentrations of GM-CSF and increased percentages of GM-CSF-expressing leukocytes (29). Based on this, blocking the IL-6 or GM-CSF pathway is expected to decrease the severity of the cytokine storm in the lungs. ii) Delayed and lowered type I interferon (IFN) response. Unlike the immune process of other respiratory viral infections, SARS-CoV-2 infection elicits delayed and lowered IFN-I and IFN-III responses, while inducing elevated chemokine expression $(30,31)$. This delayed IFN secretion is not conducive to early disease control, and instead induces more chemokines and promotes systemic inflammation and lung injury (23). This suggests that different timing of IFN administration may lead to completely different clinical effects.

iii) $T$ cell depletion and exhaustion. Lymphopenia is common in patients with COVID-19 (32). There is a significant decrease in $\mathrm{CD} 4^{+} \mathrm{T}$ cells in patients with COVID-19; however, the proportion of GM-CSF${ }^{+}$and IL- $6^{+} \mathrm{T}$ cells is 
higher in these patients (27). $\mathrm{CD} 8^{+} \mathrm{T}$ cells, B cells and natural killer (NK) cells are also drastically decreased in patients with severe cases of COVID-19 (33). In addition, exhaustion markers on $\mathrm{CD} 8^{+} \mathrm{T}$ cells, such as TIM-3, PD-1 and NKG2A are upregulated in patients with COVID-19 $(23,27,33)$, and lymphodepletion progresses in accordance with patient deterioration (22). Notably, an increase in lymphocytes tends to precede clinical recovery (34).

\section{Pathology}

On February 17, 2020, Dr Xu's team were the first to publish the lung pathology of biopsy specimens obtained from an elderly patient who had died of NCP (35). Subsequently, lung pathology from two patients with NCP who underwent lobectomy for lung tumors was also reported (36), which represented early lung pathology. The first lung autopsy pathology of a patient who had died of severe NCP was reported on February 27, 2020 (37). Combined with the pathological description in the COVID-19 guidelines in China (38), the pathological changes can be summarized as follows:

i) Lungs. On gross examination, the lungs exhibited diffuse congestion and hemorrhage, accompanied by partial hemorrhagic necrosis (37). On the cut surface, the bronchi were covered with mucus (38). Hemorrhage and necrosis were most common at the margin zone of the lungs (37).

Histopathological findings included pulmonary interstitial fibrosis, focal pulmonary hemorrhage and hemorrhagic infarction (37). Serous or fibromyxoid exudates and hyaline membranes were observed in the alveolar cavity, and the exudated cells were predominantly monocytes and macrophages (38-40). Prominent hyperplasia of type II pneumocytes was observed, and some type II pneumocytes desquamated $(39,40)$. Inclusion bodies were also observed in type II pneumocytes and macrophages. Monocyte and lymphocyte infiltration were present in the alveolar septa and the alveolar capillaries were congested, accompanied by the formation of hyaline thrombus $(38,39)$. Inflammatory cell infiltrations, including lymphocytes, plasma cells and monocytes, were exhibited in the pulmonary interstitium (39). Some of the epithelial cells in the bronchial mucosa were desquamated, and mucus plugs were observed in the lumen (38). Some alveoli were overinflated, and alveolar septa were ruptured or accompanied by cystic cavity formation. Coronavirus particles were seen in the cytoplasm of bronchial epithelial cells and type II pneumocytes under electron microscopy $\left(10^{5} \mathrm{x}\right.$ magnification) $(38,40)$. Immunohistochemical staining demonstrated that some alveolar epithelium cells and macrophages were positive for the novel coronavirus antigen $(38,40)$.

ii) Spleen, lymph nodes and bone marrow. There was significant atrophy in the spleen (38). In the spleen, the number of lymphocytes decreased significantly, focal hemorrhage and necrosis were observed, along with macrophage proliferation and phagocytosis. In the lymph nodes, low levels of lymphocytes and necrosis were observed. Immunohistochemical staining demonstrated a decrease in $\mathrm{CD} 4^{+} \mathrm{T}$ and $\mathrm{CD} 8{ }^{+} \mathrm{T}$ cells in the spleen and lymph nodes. Furthermore, the number of red blood cells, white blood cells and platelets decreased in the bone marrow. iii) Heart and blood vessels. Degeneration and necrosis of the cardiomyocytes was present (38). Several monocytes, lymphocytes and neutrophils were observed in the stroma $(38,40)$. Some vascular endothelial cells were desquamated, inflammation of the vascular intima was present and thrombosis was observed $(37,38)$.

iv) Liver and gallbladder. The liver was enlarged and dark red (38). Hepatocyte degeneration and focal necrosis with neutrophil infiltration was observed $(38,40)$. Hepatic sinus hyperemia, infiltration of lymphocytes and monocytes into the portal area, and microthrombi were present (38). The gallbladder was enlarged (38).

v) Kidneys. Proteinaceous exudate was observed in the urinary space (38). The tubular epithelial cells demonstrated degeneration and loss, and the tubular lumen contained hyaline casts. Interstitial hyperemia was exhibited, with microthrombi and focal fibrosis (38).

vi) Other organs. Focal necrosis was observed in the adrenal gland (38). The brain tissue exhibited hyperemia and edema (38). In addition, the epithelial cells of the esophagus, stomach and intestine exhibited degeneration, necrosis and desquamation at varying degrees (38).

\section{Clinical characteristics}

The incubation period was 1-14 days, most commonly 2-7 days (32). The most common symptoms included fever and coughing, and other symptoms included fatigue and sputum production $(38,41)$. Several patients had symptoms that were accompanied by headache, sore throat, shortness of breath, myalgia, arthralgia and chills. In severe cases, dyspnea and/or hypoxemia usually occurred one week after onset of the disease, and in critical cases, acute respiratory distress syndrome, septic shock, refractory metabolic acidosis, coagulation dysfunction and multiple organ failure progressed rapidly (42). Notably, some severe and critical patients developed a low-grade fever or no obvious fever in the development of the disease (38). Younger patients ( $\leq 14$ years old) may have atypical symptoms, such as vomiting, diarrhea and other gastrointestinal symptoms, or only presented a decreased mental state and shortness of breath (38). Patients with mild symptoms exhibited low-grade fever, slight fatigue and no pneumonia (38). According to the data from the Chinese Center for Disease Control and Prevention (CDC) (43), most patients had a good prognosis, whereas elderly patients with chronic underlying diseases had a poor prognosis. The clinical course of NCP in pregnant and parturient women was similar to that of other patients of the same age (38). In children, the disease was relatively mild (38).

According to a statistical analysis of 44,672 confirmed patients in mainland China by the Chinese CDC epidemiology team (43), $80.95 \%$ of the patients had mild disease symptoms, $13.81 \%$ were severe cases and $4.67 \%$ were critical (Fig. 3A). The age group with highest prevalence was 40-69 years (Fig. 3B). Statistical analysis demonstrated that fatality rate increased with age (Fig. 4). In addition, the case fatality rate was $0.9 \%$ in patients with no underlying disease, $6.0 \%$ in patients with hypertension, $7.3 \%$ in patients with diabetes, $10.5 \%$ in patients with other cardiovascular diseases, such as coronary heart disease, $6.3 \%$ in patients with underlying 

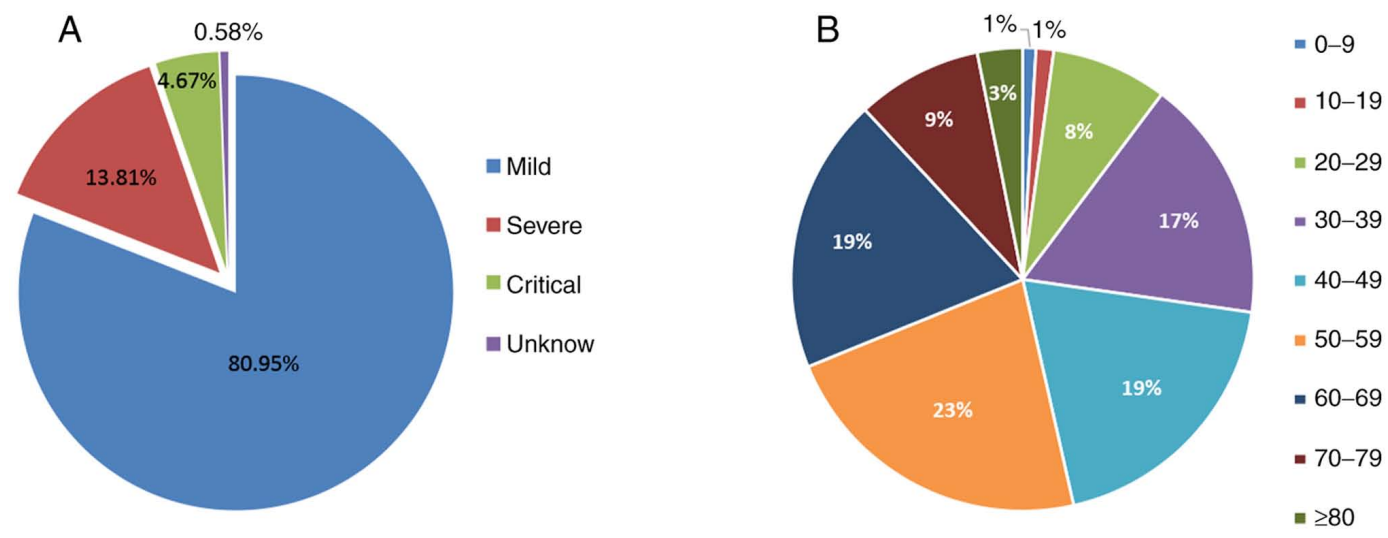

Figure 3. Diagnostic classification and age distribution of patients with COVID-19. (A) Disease diagnostic classification of 44,415 confirmed patients and (B) age distribution of 44,672 confirmed patients. Mild: The clinical symptoms are relatively mild, with no or mild manifestations of pneumonia on imaging. Severe: Any of the following; i) Respiratory distress, RR $>20$ times/min; ii) at rest, $\mathrm{SPO} 2<93 \%$ and iii) the $\mathrm{PaO}_{2} / \mathrm{FiO}_{2}<300 \mathrm{mmHg}$. Critical: Meeting one of the following conditions: i) Respiratory failure, requiring mechanical ventilation; ii) shock and iii) complications of other organ failure requiring ICU care. [Data source: ref. (10)].

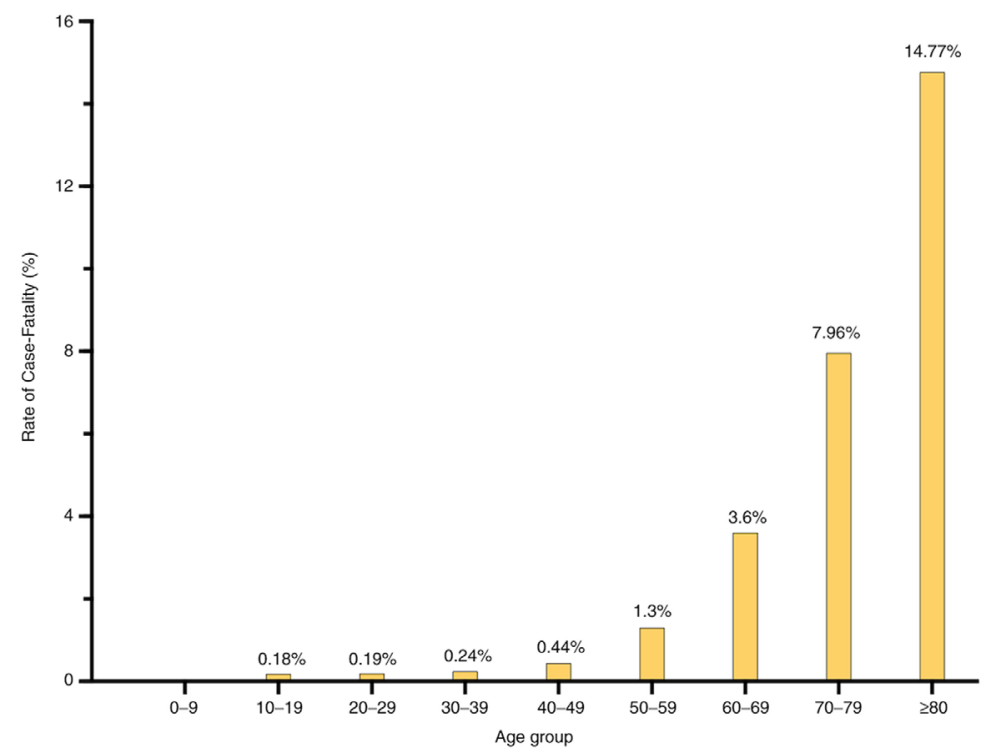

Figure 4. Case fatality rates of 44,672 confirmed cases by age group in mainland China [Data source: ref. (10)].

respiratory infections and $5.6 \%$ in patients with cancer (43) Analysis of this large sample data indicated that the case fatality rate was closely associated with patient age and whether there was any underlying disease.

\section{Laboratory and chest imaging tests}

According to the COVID-19 guidelines in China, reverse-transcription polymerase chain reaction (RT-PCR) detection and chest imaging examinations are considered the most important methods for screening and diagnosing patients with NCP (38). Pathogen related tests include qualitative detection of SARS-CoV-2 nucleic acids and screening of serum antiviral antibodies. By March 16, 2020, the China National Medical Products Administration had approved 11 SARS-CoV-2 nucleic acid detection reagents and eight antibody detection reagents (44). The methods used for PCR detection of SARS-CoV-2 nucleic acids included nucleic acid fluorescence
PCR and nucleic acid sequencing (44). Currently, approved reagents detect the novel gene segments of the coronavirus, including the open reading frame $1 \mathrm{ab}$ (ORF1ab), envelope protein $(\mathrm{E})$ and nucleocapsid protein $(\mathrm{N})$ coding region, and are classified as the single-target detection (ORF1ab), double-target detection (ORF1ab, N protein) and triple-target detection (ORF1ab, $\mathrm{N}$ protein and $\mathrm{E}$ protein). Viral nucleic acids can be detected in nasopharyngeal swabs, sputum, lower respiratory tract secretions, blood and feces via PCR or sequencing analyses. Serum antibody screening can detect antiviral antibodies IgM and IgG. The techniques used by these kits include the immune colloidal gold technique, the magnetic particle-based chemiluminescence enzyme immunoassay and the chemiluminescent microparticle immunoassay (44). The IgM antibodies against SARS-CoV-2 in serum usually appear positive 3-5 days after the onset, which indicates a recent infection, whereas $\mathrm{IgG}$ antibodies indicate convalescence or a past infection (38). 
The most common CT findings are ground-glass opacification (GGO) and bilateral consolidative opacities (45). In the early stage of the disease, the lung is characterized by single or multiple focal GGO and local patchy shadows with a peripheral distribution (46). In the progressive stage, multiple GGO, consolidative opacities, air bronchograms and interstitial abnormalities are observed in both lungs (46). In severe and critical cases, extensive consolidative opacities of both lungs are present (46). Pleural and pericardial effusion are less common. Although several cases of pulmonary inflammatory lesions begin in peripheral areas, these CT findings alone cannot easily distinguish them from other viral pneumonias (47).

The characteristics of other laboratory tests are summarized as follows (32): Blood routine examination indicates that the white cell count is normal or decreased, and lymphocytopenia $\left(<1,500 / \mathrm{mm}^{3}\right)$ is present in most patients. The majority of patients have elevated levels of C-reactive protein $(>10 \mathrm{mg} / \mathrm{l})$ and procalcitonin $(\geq 0.5 \mathrm{ng} / \mathrm{ml})$, whereas aminotransferase and creatine kinase are less often observed (26). Plasma concentrations of inflammatory mediators and cytokines, such as IL-1 $\beta$, IL-1RA, IL-7, IL-8, IL-9, IL-10, basic FGF, G-CSF, GM-CSF, IFN- $\gamma$, IP10, MCP1, MIP1A, MIP1B, PDGF, TNF- $\alpha$ and VEGF are increased (29).

\section{Treatment}

\section{Antiviral therapy}

$I F N-\alpha$. Effective antivirals and antiviral regimens are important for combating COVID-19. IFN- $\alpha$ has been extensively used in the treatment of viral infectious diseases (48). IFN, as an antiviral drug with an exact curative effect, is limited to the treatment of hepatitis B virus (HBV), hepatitis C virus (HCV), human herpes virus type $8(\mathrm{HHV}-8)$ and human papillomavirus infection (49). It is also used to treat other common viral infectious diseases, including the common cold (50), influenza (50), and mumps (51); however, the curative effects have not yet been proven in these diseases $(50,52,53)$. As early as the SARS epidemic, two studies reported the therapeutic effect of IFN combined with glucocorticoids and/or ribavirin in patients with SARS $(54,55)$. However, a subsequent systematic evaluation study revealed that there is no benefit from IIFN treatment due to the complexity of clinical intervention measures and lack of a suitable control group in the two studies (56). Although inhalation therapy with IFN- $\alpha$ is recommended by the NHC guidelines (57), and several patients with COVID-19 underwent treatment with IFN- $\alpha$ during hospitalization in China, the exact efficacy of interferon remains to be verified.

Lopinavir/ritonavir. Lopinavir/ritonavir (LPV/r), an anti-HIV drug was hypothesized to have effects on SARS and MERS (58), and was used in the treatment of patients with COVID-19 (57,59). However, a randomized, controlled, open label study from China demonstrated that LPV/r treatment of patients with severe COVID-19 did not significantly change the clinical outcome, including the mortality and oropharyngeal virus persistence time (60).

Remdesivir. Remdesivir is a broad-spectrum antiviral that has been reported to inhibit the replication of SARS-CoV and
MERS-CoV in vitro $(8,61-64)$, and has been successfully used to treat a US patient with $\mathrm{NCP}(65)$. A report of 53 patients with severe COVID-19 who were treated with compassionate-use remdesivir demonstrated improvement in the oxygen-support status of 36 patients (68\%) (66). However, the results were limited by the lack of a control group and the small sample size. In China, a double-blind, randomized, placebo-controlled trial enrolling 237 patients with severe COVID-19 demonstrated no clinical improvement in patients treated with remdesivir (67). The trial was originally scheduled to include 453 patients with COVID-19 but failed to complete full enrollment due to the end of the outbreak in China. Recently, another double-blind, randomized, placebo-controlled study of remdesivir (Adaptive COVID-19 Treatment Trial 1, ACTT-1) in 1,059 hospitalized patients with COVID-19 suggested that a 10-day course of remdesivir was superior compared with placebo in shortening the time of recovery (median days, 11 vs. 15; $\mathrm{P}<0.001)(68)$. However, given the high mortality in both groups, the report indicated that monotherapy with an antiviral drug is not likely to be sufficient. Thus, combined therapeutic approaches are urgently required to further improve patient outcomes.

Favipiravir. Favipiravir is a nucleoside analogue against the RNA-dependent RNA polymerase of some viruses, including influenza A and B (69). It has also been used as post exposure prophylaxis and was evaluated in clinical trials for Ebola virus (70-72). An open-label control study from China assessed the efficacy and safety of favipiravir on 80 patients with mild or moderate COVID-19, whereby 35 patients were assigned to favipiravir and 45 were assigned to LPV/r. The results demonstrated that patients treated with favipiravir had a shorter viral clearance time $(\mathrm{P}<0.001)$ and better radiographic improvement $(\mathrm{P}<0.01)$ compared with patients treated with LPV/r (73). Furthermore, a lower rate of adverse events, such as nausea, was observed in the favipiravir group $(\mathrm{P}<0.05)$. These preliminary clinical findings require further research.

Chloroquine and hydroxychloroquine. Chloroquine is an antimalarial drug. Hydroxychloroquine is a superior analogue of chloroquine, which possesses a more tolerable safety profile (74). Both exert anti-inflammatory effects and are extensively used in the treatment of rheumatic diseases (74). Previous in vitro experiments have demonstrated that chloroquine inhibits the replication of SARS-CoV by interfering with the binding of SARS-CoV to the ACE2 receptor of the Vero E6 cell line (75). Recent in vitro studies further supported the efficacy of chloroquine and hydroxychloroquine in inhibiting MERS-CoV-2 (76-78). Based on its antiviral effect in vitro and previous wide clinical usage in patients with a safety track record, chloroquine has been recommended for the treatment of patients with COVID-19 in China (79). However, recent clinical data seem to less promising for both chloroquine and hydroxychloroquine in COVID-19 (80). An open label, randomized controlled trial from China (148 patients with mild to moderate COVID-19 and two patients with severe COVID-19) demonstrated that the probability of negative conversion of SARS-CoV-2 in the hydroxychloroquine group was $85.4 \%$ by 28 days, which was similar to $81.3 \%$ in the standard treatment group (81). There was also no significant difference between the two groups in the time to negative 
RT-PCR test of SARS-CoV-2. A large observational study involving 1,376 patients with COVID-19, hospitalized in a medical center in New York, also demonstrated that hydroxychloroquine administration did not result in a significantly lowered or an increased risk of intubation or mortality (82). Another retrospective study analyzed the in-hospital mortality among 1,438 hospitalized patients with COVID-19 in New York who were treated with hydroxychloroquine, azithromycin, combined hydroxychloroquine and azithromycin, or neither drug. The results demonstrated that treatment with hydroxychloroquine, azithromycin, or both, did not show a significant difference in in-hospital mortality compared with neither treatment (83). In addition, hydroxychloroquine used as post exposure prophylaxis for COVID-19 did not seem to offer much hope either (84).

Anti-inflammatory drugs. Since SARS-CoV-2 can trigger hyper-inflammatory syndrome in the body (22), resulting in damage to multiple target organs, it is speculated that anti-inflammatory treatments may benefit critically ill patients. Anti-inflammatory drugs include glucocorticoids (GCS), such as dexamethasone and methylprednisolone, and non-steroidal anti-inflammatory drugs (NSAID), such as acetaminophen and ibuprofen. The use of GCS in COVID-19 pneumonia remains controversial (85-92). Early case analysis from China demonstrated that the rate of systemic GCS use was up to $18.6 \%$ in the total number of admitted patients with COVID-19, and was $44.5 \%$ in severe patients (32). Despite lack of evidence that the use of GCS in critically ill patients with COVID-19 does more good than harm, experience in dealing with SARS (93) and H1N1 (2009) (94) outbreaks has demonstrated that rational use of GCS in critically ill patients can decrease mortality and shorten hospital stays (86). Furthermore, a recent multicenter randomized controlled trial reported that dexamethasone treatment can decrease mechanical ventilation duration and overall mortality in patients with moderate-to-severe ARDS (95). Thus, the use of GCS in patients with COVID-19 cannot be generalized. The indiscriminate use of GCS will lead to secondary infection, prolonged virus shedding and disease progression (86). Thus, the Chinese expert group $(86,96)$ recommended the following: i) The advantages and disadvantages of GCS should be fully assessed prior to the prudent use of GCS in critically ill patients with pneumonia; ii) the dosage should be low to medium $(\leq 0.5-1 \mathrm{mg} / \mathrm{kg}$ per day methylprednisolone or equivalent) and iii) the duration of treatment should not exceed 7 days. Celecoxib and carprofen are NSAID drugs that were screened by computer-aided analysis, and were demonstrated to potentially exert anti-coronavirus effects (97). However, their exact efficacy requires verification via in vivo and in vitro experiments.

GM-CSF pathway inhibitors. Mavrilimumab is a humanized monoclonal antibody (mAb) (Ig4) targeting GM-CSF receptor $\alpha$, which has demonstrated efficacy and safety in phase I and phase II clinical trials in rheumatoid arthritis (RA) (98). GM-CSF is secreted by fibroblasts, macrophages, dendritic cells, T cells, neutrophils, eosinophils and tumor cells (99). Analysis of serum cytokine levels in 41 patients with COVID-19 demonstrated that these patients had higher GM-CSF levels compared with healthy controls (29). De Luca et al (99) recently performed a prospective study on mavrilimumab in non-mechanically ventilated patients with COVID-19 pneumonia and systemic hyperinflammation. The results demonstrated that all 13 patients in the mavrilimumab treatment group exhibited clinical improvement compared with $17 / 26$ patients $(65 \%)$ in the control group, who received standard care $(\mathrm{P}=0.030)$, and treatment of mavrilimumab was well tolerated.

Lenzilumab is a recombinant humanized anti-GM-CSF $\mathrm{mAb}$ (100). The GM-CSF signaling to myeloid progenitor cells is blocked by lenzilumab through neutralization of GM-CSF, which prevents GM-CSF binding to the receptor (101). Lenzilumab has been implemented in clinical trials for patients with eosinophilic asthma, RA, chronic myelomonocytic leukemia and cytokine release syndrome associated with chimeric antigen receptor T (CAR-T) cell therapy (28). The clinical use of lenzilumab in 12 patients with severe or critical COVID-19 pneumonia demonstrated that lenzilumab may improve oxygenation and decrease serum levels of cytokines, such as IL-6, G-CSF, IL-1a and IL-12p70 (102). Gimsilumab, developed by Roivant Sciences, is another recombinant human anti-GM-CSF $\mathrm{mAb}$ (28). The phase I study on gimsilumab for ARDS in COVID-19 has been completed (results unpublished) and the phase II clinical trial is underway. Results from these clinical trials verified the association between GM-CSF and the overactivated immune response in severe and critical COVID-19 pneumonia (27). Thus, blocking the GM-CSF pathway is a potential treatment for severe COVID-19.

IL-6 inhibitors. Tocilizumab is a recombinant $\mathrm{mAb}$ against the IL-6 receptor (IL-6R) and has been approved for the treatment of RA and giant cell arteritis (103). IL-6 is the main inducer of the acute phase response (104) and is classified as an important infection-related marker (105-107). Due to high levels of IL-6 observed in severely ill patients, tocilizumab treatment in these patients may decrease lung damage (27). In a recent report, 21 patients with severe or critical COVID-19 were treated with tocilizumab and the clinical symptoms notably improved, with no significant adverse events observed (108). However, the study's credibility was limited by the lack of a control group. In China, tocilizumab has been recommended for the treatment of severe COVID-19 pneumonia with high IL-6 levels (38). As of September 11, 2020, there are currently 38 clinical trials involving tocilizumab for the treatment of COVID-19 registered at clinicaltrials.gov. Sarilumab is another humanized anti-IL-6R mAb approved for the treatment of RA (103). According to clinicaltrials.gov, eight clinical trials are underway to assess the safety and efficacy of sarilumab in the treatment of COVID-19.

Janus kinase (JAK) pathway inhibitors. Baricitinib, an approved drug for the treatment of RA, is a reversible inhibitor of the intracellular signaling molecule, JAK (109). Baricitinib inhibits the production of multiple cytokines by suppressing the JAK-signal transducer and activator of transcription (STAT) signaling pathway, thus producing anti-inflammatory effects (110). Another advantage of baricitinib is its in vitro anti-coronavirus activity (111-113), which is mediated by 
suppressing endocytosis-associated enzymes adaptor-associated kinase-1 (AAK1) and cyclin G-associated kinase (GAK) (111). A recent open-label pilot study demonstrated that baricitinib may significantly improve clinical and laboratory parameters, including fever, $\mathrm{SPO}_{2}$, Horowitz Index and CRP, in patients with moderate COVID-19 pneumonia (114). The ACTT-2 led by the US National Institute of Allergy and Infectious Diseases is recruiting to assess the effectiveness and safety of remdesivir and baricitinib in treating COVID-19 (115). The trial is based on ACTT-1 to determine whether JAK inhibitors can provide extra benefits to patients, including decreasing mortality (116).

Convalescent plasma therapy. Convalescent plasma is collected from patients who have recovered from COVID-19. In China, the time of blood donation should be at least 3 weeks after the onset of COVID-19 symptoms. Convalescent plasma contains virus-specific neutralizing antibodies, which can directly bind the virus and eliminate it via cellular cytotoxicity and phagocytosis (117). For those with coagulation disorders, plasma transfusion can also replenish coagulation factors (118). Thus, convalescent plasma transfusion may be beneficial to patients with severe COVID-19. Convalescent plasma has been used for treatment of viral infectious diseases, such as SARS, H5N1 avian influenza, Ebola hemorrhagic fever and MERS (119). It has also been used in patients with severe COVID-19. Some COVID-19 cases exhibited a clinical benefit, including improvement in oxygenation, the sequential organ failure assessment (SOFA) scores and other clinic status (120-123). However, a recent open-label randomized clinical trial of 103 patients with severe COVID-19 given convalescent plasma did not result in a significant improvement in time to clinical improvement within 28 days compared with standard treatment alone (124). There are currently more than 70 ongoing registered clinical trials globally assessing the efficacy of convalescence plasma in the treatment of COVID-19.

Vaccine. Given the persistence of the COVID-19 epidemic and the inaccessibility of specific drugs, vaccine research is of great significance for preventing further development and potential future epidemic peaks. An optimal vaccine for SARS-CoV-2 would elicit long-lasting antibody protective effects, an effective T-cell response, simultaneously avoid generating antibody-dependent enhancement (ADE) and a skewed Th2 immune response (125).

Currently, there are over 100 COVID-19 vaccines under development worldwide. According to the design strategy, these vaccines can be classified into four categories (126), as follows: i) virus vaccines; ii) nucleic-acid vaccines; iii) viral-vector vaccines; and iv) protein-based vaccines. The most common vaccines for SARS-COV-2 are protein-based and adenovirus vectored vaccines, and most of these vaccine trials are pre-clinical (126). The PiCoVacc and BBIBP-CorV inactivated virus vaccine candidates have exhibited effective protection against SARS-CoV-2 in animal experiments $(127,128)$. Currently, there are eight registered clinical phase I or II vaccine trials worldwide, including Moderna's and BioNTech's mRNA COVID-19 vaccines, Inovio Pharmaceuticals' DNA vaccine, three inactivated COVID-19 vaccines manufactured by Sinovac (Wuhan and Beijing Institute of Biological Products), University of Oxford's non-replicating chimpanzee adenovirus vectored vaccine (also known as ChAdOx1 nCOV-19) and CanSino's non-replicating adenovirus type 5 vectored vaccine $(\mathrm{Ad} 5-\mathrm{nCoV})(125,128)$. The phase I study of Ad5-nCoV has been completed, and the results demonstrated that $\mathrm{Ad} 5-\mathrm{nCoV}$ has good safety and can induce specific antibodies against the viral spike proteins and specific $\mathrm{T}$ cell responses to SARS-CoV-2 (128); however, it still requires verification in phase II clinical trials.

\section{Conclusion}

Since the COVID-19 outbreak in Wuhan, the Chinese government and Chinese people have made great efforts to control the development and spread of the epidemic. These controls include: Restricting and decreasing outdoor activities, home isolation, banning gatherings, introducing population screening and education, accelerating the admission and treatment of confirmed patients, accelerating the supply of medical necessities, strengthening the research and development of diagnostic reagents, and mobilizing all citizens to participate in the prevention and control of the epidemic.

Although the severity of the epidemic has greatly decreased, a significant amount of work remains. Future endeavors should aim to identify the origin of the coronavirus, clarify the pathogenesis of COVID-19, hasten the research and development of antiviral drugs and vaccines, and discuss how to establish a global prevention and control system for emerging infectious diseases.

\section{Acknowledgements}

Not applicable.

\section{Funding}

The present study was partially supported by a grant from the Sanming Project of Medicine in Shenzhen (grant no. SZSM201612034).

\section{Availability of data and materials}

All data generated or analyzed during the present study are included in this published article.

\section{Authors' contributions}

HC drafted the initial manuscript. SW and XZ revised the manuscript. All authors have read and approved the final manuscript.

\section{Ethics approval and consent to participate}

Not applicable.

\section{Patient consent for publication}

Not applicable. 


\section{Competing interests}

The authors declare that they have no competing interests.

\section{References}

1. Lu R, Zhao X, Li J, Niu P, Yang B, Wu H, Wang W, Song H, Huang B, Zhu N, et al: Genomic characterisation and epidemiology of 2019 novel coronavirus: Implications for virus origins and receptor binding. Lancet 395: 565-574, 2020.

2. Tan WJ, Zhao X, Ma XJ, Wang W, Niu P, Xu W, Gao GF and Wu G: A novel coronavirus genome identified in a cluster of pneumonia cases-Wuhan, China 2019-2020. China CDC Weekly 2: 61-62, 2020.

3. Zhou P, Yang XL, Wang XG, Hu B, Zhang L, Zhang W, Si HR, Zhu Y, Li B, Huang CL, et al: A pneumonia outbreak associated with a new coronavirus of probable bat origin. Nature 579 $270-273,2020$

4. Coronaviridae Study Group of the International Committee on Taxonomy of Viruses: The species Severe acute respiratory syndrome-related coronavirus: Classifying 2019-nCoV and naming it SARS-CoV-2. Nat Microbiol 5: 536-544, 2020.

5. World Health Organization (WHO): Novel coronavirus disease namedCOVID-19.WHO,Geneva,2020.https://www.who.int/emergencies/diseases/novel-coronavirus-2019/events-as-they-happen. Accessed February 11, 2020.

6. Xiang N, Havers F, Chen T, Song Y, Tu W, Li L, Cao Y, Liu B, Zhou L, Meng L, et al: Use of national pneumonia surveillance to describe influenza $\mathrm{A}(\mathrm{H} 7 \mathrm{~N} 9)$ virus epidemiology, China, 2004-2013. Emerg Infect Dis 19: 1784-1790, 2013.

7. European Centre for Disease Prevention and Control: Risk assessment: Outbreak of acute respiratory syndrome associated with a novel coronavirus, Wuhan, China. https://www. ecdc.europa.eu/sites/default/files/documents/Risk-assessmentpneumonia-Wuhan-China-22-Jan-2020.pdf. Accessed January 22 2020 .

8. Zhu N, Zhang D, Wang W, Li X, Yang B, Song J, Zhao X, Huang B, Shi W, Lu R, et al: A novel coronavirus from patients with pneumonia in China, 2019. N Engl J Med 382: 727-733, 2020.

9. Cohen E: Super spreaders in coronavirus outbreaks. CNN health, 2020. https://edition.cnn.com/2020/01/23/health/wuhan-virussuper-spreader/index.html. Accessed January 23, 2020.

10. China Centre for Disease Prevention and Control: Distribution of COVID-19 outbreaks. http://2019ncov.chinacdc.cn/2019-nCoV.

11. Chutian Metropolis Daily: Central steering group: Over 60,000 beds were completed in wuhan in one month, equivalent to the construction of 60 tertiary hospitals. http://news.cnhubei com/content/2020-03/06/content_12823832.html. Accessed March 6, 2020

12. Ren LL, Wang YM, Wu ZQ, Xiang ZC, Guo L, Xu T, Jiang YZ, Xiong Y, Li YJ, Li XW, et al: Identification of a novel coronavirus causing severe pneumonia in human: A descriptive study. Chin Med J (Engl) 133: 1015-1024, 2020.

13. Xu X, Chen P, Wang J, Feng J, Zhou H, Li X, Zhong W and Hao P: Evolution of the novel coronavirus from the ongoing Wuhan outbreak and modeling of its spike protein for risk of human transmission. Sci China Life Sci 63: 457-460, 2020.

14. Lan J, Ge J, Yu J, Shan S, Zhou H, Fan S, Zhang Q, Shi X, Wang Q, Zhang L and Wang X: Structure of the SARS-CoV-2 spike receptor-binding domain bound to the ACE2 receptor. Nature 581: 215-220, 2020

15. Shang J, Ye G, Shi K, Wan Y, Luo C, Aihara H, Geng Q, Auerbach A and Li F: Structural basis of receptor recognition by SARS-CoV-2. Nature 581: 221-224, 2020.

16. Hoffmann M, Kleine-Weber H, Schroeder S, Krüger N, Herrler T, Erichsen S, Schiergens TS, Herrler G, Wu NH, Nitsche A, et al: SARS-CoV-2 cell entry depends on ACE2 and TMPRSS2 and is blocked by a clinically proven protease inhibitor. Cell 181 : 271-280.e278, 2020

17. Wang Q, Zhang Y, Wu L, Niu S, Song C, Zhang Z, Lu G, Qiao C, Hu Y, Yuen KY, et al: Structural and functional basis of SARS-CoV-2 entry by using human ACE2. Cell 181: 894-904. e9, 2020

18. Ji W, Wang W, Zhao X, Zai J and Li X: Cross-species transmission of the newly identified coronavirus 2019-nCoV. J Med Virol 92: 433-440, 2020.
19. South China Agricultural University: Press conference of scientific research on novel coronavirus pneumonia outbreak. Guangzhou, 7 February, 2020.

20. Tang XL, Wu CC, Li X, Song YH, Yao XM, Wu XK, Duan YG, Zhang H, Wng YR, Qian ZH, et al: On the origin and continuing evolution of SARS-CoV-2. Natl Sci Rev 7: 1012-1023, 2020.

21. Khiali S, Khani E and Entezari-Maleki T: A comprehensive review on tocilizumab in COVID-19 acute respiratory distress syndrome. J Clin Pharmacol: June 18, 2020 (Epub ahead of print).

22. Tay MZ, Poh CM, Rénia L, MacAry PA and Ng LEP: The trinity of COVID-19: Immunity, inflammation and intervention. Nat Rev Immunol 20: 363-374, 2020.

23. Vardhana $\mathrm{S}$ and Wolchok $\mathrm{J}$ : The many faces of the anti-COVID immune response. J Exp Med 217: e20200678, 2020.

24. Lew TW, Kwek TK, Tai D, Earnest A, Loo S, Singh K, Kwan KM, Chan Y, Yim CF, Bek SL, et al: Acute respiratory distress syndrome in critically Ill patients with severe acute respiratory syndrome. JAMA 290: 374-380, 2003.

25. Drosten C, Seilmaier M, Corman VM, Hartmann W, Scheible G, Sack S, Guggemos W, Kallies R, Muth D, Junglen S, et al: Clinical features and virological analysis of a case of Middle East respiratory syndrome coronavirus infection. Lancet Infect Dis 13: 745-751, 2013.

26. Moore B and June C: Cytokine release syndrome in severe COVID-19. Science 368: 473-474, 2020.

27. Zhou Y, Fu B, Zheng X, Wang D, Zhao C, Qi Y, Sun R, Tian Z, $\mathrm{Xu} \mathrm{X}$ and Wei $\mathrm{H}$ : Pathogenic T-cells and inflammatory monocytes incite inflammatory storms in severe COVID-19 patients. Natl Sci Rev 7: 998-1002, 2020.

28. Lang F,Lee K, Teijaro J, Becher B and Hamilton J: GM-CSF-based treatments in COVID-19: Reconciling opposing therapeutic approaches. Nat Rev Immunol 20: 507-514, 2020.

29. Huang C, Wang Y, Li X, Ren L, Zhao J, Hu Y, Zhang L, Fan G, Xu J, Gu X, et al: Clinical features of patients infected with 2019 novel coronavirus in Wuhan, China. Lancet 395: 497-506, 2020.

30. Blanco-Melo D, Nilsson-Payant B, Liu WC, Uhl S, Hoagland D, Møller R, Jordan T, Oishi K, Panis M, Sachs D, et al: Imbalanced host response to SARS-CoV-2 drives development of COVID-19. Cell 181: 1036-1045.e9, 2020.

31. Park A and Iwasaki A: Type I and Type III interferons-induction, signaling, evasion, and application to combat COVID-19. Cell Host Microbe 27: 870-878, 2020.

32. Guan W, Ni Z, Hu Y, Liang W, Ou C, He J, Liu L, Shan H, Lei C, Hui DSC, et al: Clinical characteristics of coronavirus disease 2019 in China. N Engl J Med 382: 1708-1720, 2020.

33. Cao X: COVID-19: Immunopathology and its implications for therapy. Nat Rev Immunol 20: 269-270, 2020.

34. Chen X, Ling J, Mo P, Zhang Y, Jiang Q, Ma Z, Cao Q, Hu W, Zou S, Chen L, et al: Restoration of leukomonocyte counts is associated with viral clearance in COVID-19 hospitalized patients. medRxiv: https://doi.org/10.1101/2020.03.03.200304 37.

35. Xu Z, Shi L, Wang Y, Zhang J, Huang L, Zhang C, Liu S, Zhao P, Liu H, Zhu L, et al: Pathological findings of COVID-19 associated with acute respiratory distress syndrome. Lancet Respir Med 8: 420-422, 2020.

36. Tian S, Hu W, Niu L, Liu H, Xu H and Xiao SY: Pulmonary pathology of early-phase 2019 novel coronavirus (COVID-19) pneumonia in two patients with lung cancer. J Thorac Oncol 15: 700-704, 2020.

37. Luo W, Yu H, Gou J, Li X, Sun Y, Li J and Liu L: Clinical pathology of critical patient with novel coronavirus pneumonia (COVID-19): Pulmonary fibrosis and vascular changes including microthrombosis formation. Preprint: doi: 10.13140/ RG.2.2.22934.29762.

38. General Office of National Health Commission: Diagnosis and treatment of novel coronavirus pneumonia (trial version seventh) (In Chinese). http://www.nhc.gov.cn/yzygj/s7653p/202003/46c9 294a7dfe4cef80dc7f5912eb1989/files/ce3e6945832a438eaae415 350a8ce964.pdf.

39. Carsana L, Sonzogni A, Nasr A, Rossi R, Pellegrinelli A, Zerbi P, Rech R, Colombo R, Antinori S, Corbellino M, et al: Pulmonary post-mortem findings in a series of COVID-19 cases from northern Italy: A two-centre descriptive study. Lancet Infect Dis 20: 1135-1140, 2020.

40. Deshmukh V, Motwani D, Kumar A, Kumari C and Raza K: Histopathological observations in COVID-19: A systematic review. J Clin Pathol: Aug 18, 2020 (Epub ahead of print). 
41. Docherty A, Harrison E, Green C, Hardwick H, Pius R, Norman L, Holden K, Read J, Dondelinger F, Carson G, et al: Features of $20133 \mathrm{UK}$ patients in hospital with covid-19 using the ISARIC WHO clinical characterisation protocol: Prospective observational cohort study. BMJ 369: m1985, 2020.

42. Li L, Li R, Wu Z, Yang X, Zhao M, Liu J and Chen D: Therapeutic strategies for critically ill patients with COVID-19. Ann Intensive Care 10: 45, 2020.

43. The Novel Coronavirus Pneumonia Emergency Response Epidemiology Team: The epidemiological characteristics of an outbreak of 2019 novel coronavirus diseases (COVID-19)-China, 2020. China CDC Weekly 2: 113-122, 2020.

44. China National Medical Products Administration: Novel Coronavirus detection product is subject to emergency approval by the China National Medical Products Administration. https://www.nmpa.gov. cn/zhuanti/yqyjzxd/yqyjxd/20200316153801928.html. Accessed March 16, 2020.

45. Shi H, Han X, Jiang N, Cao Y, Alwalid O, Gu J, Fan Y and Zheng C: Radiological findings from 81 patients with COVID-19 pneumonia in Wuhan, China: A descriptive study. Lancet Infect Dis 20: 425-434, 2020.

46. Dong D, Tang Z, Wang S, Hui H, Gong L, Lu Y, Xue Z, Liao H, Chen F, Yang F, et al: The role of imaging in the detection and management of COVID-19: A review. IEEE Rev Biomed Eng: Apr 27, 2020 (Epub ahead of print).

47. Dai W, Zhang H, Yu J, Xu H, Chen H, Luo S, Zhang H, Liang L, Wu X, Lei Y, et al: CT imaging and differential diagnosis of COVID-19. Can Assoc Radiol J 71: 195-200, 2020.

48. Wang N, Zhan Y, Zhu L, Hou Z, Liu F, Song P, Qiu F, Wang X Zou X, Wan D, et al: Retrospective multicenter cohort study shows early interferon therapy is associated with favorable clinical responses in COVID-19 patients. Cell Host Microbe 28 455-464.e2, 2020.

49. Balfour HH Jr: Antiviral drugs. N Engl J Med 340: 1255-1268, 1999.

50. Bergman SJ, Ferguson MC and Santanello C: Interferons as therapeutic agents for infectious diseases. Infect Dis Clin North Am 25: 819-834, 2011.

51. Rüther U, Stilz S, Röhl E, Nunnensiek C, Rassweiler J, Dörr U and Jipp P: Successful interferone-alpha 2 a therapy for a patient with acute mumps orchitis. Eur Urol 27: 174-176, 1995.

52. Hayden FG, Kaiser DL and Albrecht JK: Intranasal recombinant alfa-2b interferon treatment of naturally occurring common colds. Antimicrob Agents Chemother 32: 224-230, 1988.

53. Grennan D: Mumps. JAMA 322: 1022, 2019

54. Loutfy MR, Blatt LM, Siminovitch KA, Ward S, Wolff B, Lho H, Pham DH, Deif H, LaMere EA, Chang M, et al: Interferon alfacon-1 plus corticosteroids in severe acute respiratory syndromea preliminary study. JAMA 290: 3222-3228, 2003.

55. Zhao Z, Zhang F, Xu M, Huang K, Zhong W, Cai W, Yin Z Huang S, Deng Z, Wei M, et al: Description and clinical treatment of an early outbreak of severe acute respiratory syndrome (SARS) in Guangzhou, PR China. J Med Microbiol 52: 715-720, 2003.

56. Stockman LJ, Bellamy R and Garner P: SARS: Systematic review of treatment effects. PLoS Med 3: e343, 2006.

57. Peng F, Tu L, Yang Y, Hu P, Wang R, Hu Q, Cao F, Jiang T, Sun J, Xu G and Chang C: Management and treatment of COVID-19: The Chinese experience. Can J Cardiol 36: 915-930, 2020.

58. Chen F, Chan KH, Jiang Y, Kao RY, Lu HT, Fan KW, Cheng VC, Tsui WH, Hung IF, Lee TS, et al: In vitro susceptibility of 10 clinical isolates of SARS coronavirus to selected antiviral compounds. J Clin Virol 31: 69-75, 2004.

59. Chen N, Zhou M, Dong X, Qu J, Gong F, Han Y, Qiu Y, Wang J, Liu Y, Wei Y, et al: Epidemiological and clinical characteristics of 99 cases of 2019 novel coronavirus pneumonia in Wuhan, China: A descriptive study. Lancet 395: 507-513, 2020.

60. Cao B, Wang Y, Wen D, Liu W, Wang J, Fan G, Ruan L, Song B, Cai Y, Wei M, et al: A Trial of Lopinavir-Ritonavir in adults hospitalized with severe Covid-19. N Engl J Med 382: 1787-1799, 2020.

61. Gordon CJ, Tchesnokov EP, Feng JY, Porter DP and Götte M: The antiviral compound remdesivir potently inhibits RNA-dependent RNA polymerase from Middle East respiratory syndrome coronavirus. J Biol Chem 295: 4773-4779, 2020.

62. de Wit E, Feldmann F, Cronin J, Jordan R, Okumura A, Thomas T, Scott D, Cihlar T and Feldmann H: Prophylactic and therapeutic remdesivir (GS-5734) treatment in the rhesus macaque model of MERS-CoV infection. Proc Natl Acad Sci USA 117: 6771-6776, 2020.
63. Agostini M, Andres E, Sims A, Graham R, Sheahan T, Lu X, Smith E, Case J, Feng J, Jordan R, et al: Coronavirus susceptibility to the antiviral remdesivir (GS-5734) is mediated by the viral polymerase and the proofreading exoribonuclease. mBio 9: e00221-18, 2018

64. Sheahan TP, Sims AC, Graham RL, Menachery VD, Gralinski LE, Case JB, Leist SR, Pyrc K, Feng JY, Trantcheva I, et al: Broad-spectrum antiviral GS-5734 inhibits both epidemic and zoonotic coronaviruses. Sci Transl Med 9: eaal3653, 2017.

65. Holshue ML, DeBolt C, Lindquist S, Lofy KH, Wiesman J, Bruce H, Spitters C, Ericson K, Wilkerson S, Tural A, et al: First Case of 2019 Novel Coronavirus in the United States. N Engl J Med 382: 929-936, 2020.

66. Grein J, Ohmagari N, Shin D, Diaz G, Asperges E, Castagna A, Feldt T, Green G, Green ML, Lescure FX, et al: Compassionate use of remdesivir for patients with severe Covid-19. N Engl J Med 382: 2327-2336, 2020.

67. Wang Y, Zhang D, Du G, Du R, Zhao J, Jin Y, Fu S, Gao L, Cheng Z,Lu Q, et al: Remdesivir in adults with severe COVID-19: A randomised, double-blind, placebo-controlled, multicentre trial. Lancet 395: 1569-1578, 2020.

68. Beigel JH, Tomashek KM and Dodd LE: Remdesivir for the treatment of Covid-19-preliminary report. N Engl J Med 383: 994, 2020.

69. Coomes EA and Haghbayan H: Favipiravir, an antiviral for COVID-19? J Antimicrob Chemother 75: 2013-2014, 2020.

70. Jacobs M, Aarons E, Bhagani S, Buchanan R, Cropley I, Hopkins S, Lester R, Martin D, Marshall N, Mepham S, et al: Post-exposure prophylaxis against Ebola virus disease with experimental antiviral agents: A case-series of health-care workers. Lancet Infect Dis 15: 1300-1304, 2015.

71. Bai CQ, Mu JS, Kargbo D, Song YB, Niu WK, Nie WM, Kanu A, Liu WW, Wang YP, Dafae F, et al: Clinical and virological characteristics of ebola virus disease patients treated with favipiravir (T-705)-Sierra Leone, 2014. Clin Infect Dis 63: 1288-1294, 2016.

72. Sissoko D, Laouenan C, Folkesson E, M'Lebing A-B, Beavogui A-H, Baize S, Camara A-M, Maes P, Shepherd S, Danel $\mathrm{C}$, et al: Experimental treatment with favipiravir for ebola virus disease (the JIKI trial): A historically controlled, single-arm proof-of-concept trial in Guinea. PLoS Med 13: e1001967, 2016.

73. Cai Q, Yang M, Liu D, Chen J, Shu D, Xia J, Liao X, Gu Y, Cai Q, Yang Y, et al: Experimental treatment with favipiravir for COVID-19: An open-label control study. Engineering (Beijing): Mar 18, 2020. (Epub ahead of print).

74. Rainsford KD, Parke AL, Clifford-Rashotte M and Kean WF: Therapy and pharmacological properties of hydroxychloroquine and chloroquine in treatment of systemic lupus erythematosus, rheumatoid arthritis and related diseases. Inflammopharmacology 23: 231-269, 2015.

75. Keyaerts E, Vijgen L, Maes P, Neyts J and Van Ranst M: In vitro inhibition of severe acute respiratory syndrome coronavirus by chloroquine. Biochem Biophys Res Commun 323: 264-268, 2004.

76. Wang M, Cao R, Zhang L, Yang X, Liu J, Xu M, Shi Z, Hu Z, Zhong W and Xiao G: Remdesivir and chloroquine effectively inhibit the recently emerged novel coronavirus $(2019-\mathrm{nCoV})$ in vitro. Cell Res 30: 269-271, 2020.

77. Yao X, Ye F, Zhang M, Cui C, Huang B, Niu P, Liu X, Zhao L, Dong E, Song C, et al: In vitro antiviral activity and projection of optimized dosing design of hydroxychloroquine for the treatment of severe acute respiratory syndrome coronavirus 2 (SARS-CoV-2). Clin Infect Dis 71: 732-739, 2020.

78. Liu J, Cao R, Xu M, Wang X, Zhang H, Hu H, Li Y, Hu Z, Zhong $\mathrm{W}$ and Wang M: Hydroxychloroquine, a less toxic derivative of chloroquine, is effective in inhibiting SARS-CoV-2 infection in vitro. Cell Discovery 6: 16, 2020.

79. Multicenter collaboration group of Department of Science and Technology of Guangdong Province and Health Commission of Guangdong Province for chloroquine in the treatment of novel coronavirus pneumonia: Expert consensus on chloroquine phosphate for the treatment of novel coronavirus pneumonia. Zhonghua Jie He He Hu Xi Za Zhi 43: 185-188, 2020 (In Chinese).

80. Kupferschmidt K: Big studies dim hopes for hydroxychloroquine. Science 368: 1166-1167, 2020.

81. Tang W, Cao Z, Han M, Wang Z, Chen J, Sun W, Wu Y, Xiao W, Liu S, Chen E, et al: Hydroxychloroquine in patients with mainly mild to moderate coronavirus disease 2019: Open label, randomised controlled trial. BMJ 369: m1849, 2020. 
82. Geleris J, Sun Y, Platt J, Zucker J, Baldwin M, Hripcsak G, Labella A, Manson DK, Kubin C, Barr RG, et al: Observational study of hydroxychloroquine in hospitalized patients with Covid-19. N Engl J Med 382: 2411-2418, 2020.

83. Rosenberg ES, Dufort EM, Udo T, Wilberschied LA, Kumar J, Tesoriero J, Weinberg P, Kirkwood J, Muse A, DeHovitz J, et al: Association of treatment with hydroxychloroquine or azithromycin with in-hospital mortality in patients with COVID-19 in New York state. JAMA 323: 2493-2502, 2020.

84. Boulware DR, Pullen MF, Bangdiwala AS, Pastick KA, Lofgren SM, Okafor EC, Skipper CP, Nascene AA, Nicol MR, Abassi M, et al: A randomized trial of hydroxychloroquine as postexposure prophylaxis for Covid-19. N Engl J Med 383: $517-525,2020$

85. Fadel R, Morrison Austin R, Vahia A, Smith ZR, Chaudhry Z, Bhargava P, Miller J, Kenney RM, Alangaden G and Ramesh MS Henry Ford COVID-19 Management Task Force: Early short course corticosteroids in hospitalized patients with COVID-19. Clin Infect Dis: May 19, 2020 (Epub ahead of print).

86. Shang L, Zhao J, Hu Y, Du R and Cao B: On the use of corticosteroids for 2019-nCoV pneumonia. Lancet 395: 683-684, 2020

87. Yazdanpanah F, Hamblin MR and Rezaei N: The immune system and COVID-19: Friend or foe? Life Sciences 256: 117900, 2020

88. Kolilekas L, Loverdos K, Giannakaki S, Vlassi L, Levounets A Zervas E and Gaga M: Can steroids reverse the severe COVID-19 induced 'cytokine storm'? J Med Virol: Jun 12, 2020 (Epub ahead of print).

89. Taboada M, Caruezo V, Naveira A and Atanassoff PG: Corticosteroids and the hyper-inflammatory phase of the COVID-19 disease. J Clin Anesth 66: 109926, 2020.

90. Russell CD, Millar JE and Baillie JK: Clinical evidence does not support corticosteroid treatment for 2019-nCoV lung injury. Lancet 395: 473-475, 2020.

91. Li H, Chen C, Hu F, Wang J, Zhao Q, Gale RP and Liang Y: Impact of corticosteroid therapy on outcomes of persons with SARS-CoV-2, SARS-CoV, or MERS-CoV infection: A systematic review and meta-analysis. Leukemia 34: 1503-1511, 2020.

92. Zha L, Li S, Pan L, Tefsen B, Li Y, French N, Chen L, Yang G and Villanueva EV: Corticosteroid treatment of patients with coronavirus disease 2019 (COVID-19). Med J Aust 212: 416-420, 2020

93. Chen RC, Tang XP, Tan SY, Liang BL, Wan Z, Fang JQ and Zhong N: Treatment of severe acute respiratory syndrome with glucosteroids. Chest 129: 1441-1452, 2006.

94. Li H, Yang S, Gu L, Zhang Y, Yan X, Liang Z, Zhang W, Jia H, Chen W, Liu M, et al: Effect of low-to-moderate-dose corticosteroids on mortality of hospitalized adolescents and adults with influenza A(H1N1)pdm09 viral pneumonia. Influenza Other Respir Viruses 11: 345-354, 2017.

95. Villar J, Ferrando C, Martínez D, Ambrós A, Muñoz T, Soler JA Aguilar G, Alba F, González-Higueras E, Conesa LA, et al: Dexamethasone treatment for the acute respiratory distress syndrome: A multicentre, randomised controlled trial. Lancet Respir Med 8: 267-276, 2020

96.Zhao JP, Hu Y, Du RH, Chen ZS, Jin Y, Zhou M, J Z, Qu JM and $B$ C: Expert consensus on the use of corticosteroid in patients with 2019-nCoV pneumonia. Zhonghua Jie He He Hu Xi Za Zhi 43: E007, 2020 (In Chinese).

97. Gimeno J, Mestres-Truyol J, Ojeda-Montes MJ, Macip G, Saldivar-Espinoza B, Cereto-Massagué A, Pujadas G and Garcia-Vallvé S: Prediction of novel inhibitors of the main protease (M-pro) of SARS-CoV-2 through consensus Docking and drug reposition. Int J Mol Sci 21: 3793, 2020.

98. Burmester GR, Feist E, Sleeman MA, Wang B, White B and Magrini F: Mavrilimumab, a human monoclonal antibody targeting GM-CSF receptor- $\alpha$, in subjects with rheumatoid arthritis: A randomised, double-blind, placebo-controlled, phase I, first-in-human study. Ann Rheum Dis 70: 1542-1549, 2011.

99. De Luca G, Cavalli G,Campochiaro C, Della-Torre E, Angelillo P, Tomelleri A, Boffini N, Tentori S, Mette F, Farina N, et al: GM-CSF blockade with mavrilimumab in severe COVID-19 pneumonia and systemic hyperinflammation: A single-centre, prospective cohort study. Lancet Rheumatol 2: e465-e 473, 2020

100. Vijayvargiya P, Esquer Garrigos Z, Castillo Almeida NE, Gurram PR, Stevens RW and Razonable RR: Treatment considerations for COVID-19: A critical review of the evidence (or Lack Thereof). Mayo Clin Proc 95, 1454-1466, 2020.

101. Temesgen Z, Assi M, Shweta FNU, Vergidis P, Rizza SA, Bauer PR, Pickering BW, Razonable RR, Libertin CR, Burger CD, et al: GM-CSF neutralization with lenzilumab in severe COVID-19 pneumonia: A case-control study. Mayo Clin Proc, 2020.
102. Temesgen Z, Assi M, Vergidis P, Rizza SA, Bauer PR, Pickering BW, Razonable RR, Libertin CR, Burger CD, Orenstein R, et al: First clinical use of lenzilumab to neutralize GM-CSF in patients with severe COVID-19 pneumonia. medRx iv 2020.2006.2008.20125369, 2020.

103. Alijotas-Reig J, Esteve-Valverde E, Belizna C, SelvaO'Callaghan A, Pardos-Gea J, Quintana A, Mekinian A, Anunciacion-Llunell A and Miró-Mur F: Immunomodulatory therapy for the management of severe COVID-19. Beyond the anti-viral therapy: A comprehensive review. Autoimmun Rev 19: 102569, 2020.

104. Garbers C, Heink S, Korn T and Rose-John S: Interleukin-6: Designing specific therapeutics for a complex cytokine. Nat Rev Drug Discov 17: 395-412, 2018

105. Pfäfflin A and Schleicher E: Inflammation markers in point-of-care testing (POCT). Anal Bioanal Chem 393: 1473-1480, 2009.

106. Bloos F and Reinhart K: Rapid diagnosis of sepsis. Virulence 5: 154-160, 2014

107. Ma L, Zhang H, Yin Y, Guo W, Ma Y, Wang Y, Shu C and Dong L: Role of interleukin- 6 to differentiate sepsis from non-infectious systemic inflammatory response syndrome. Cytokine 88: 126-135, 2016

108. Xu X, Han M, Li T, Sun W, Wang D, Fu B, Zhou Y, Zheng X, Yang Y, Li X, et al: Effective treatment of severe COVID-19 patients with tocilizumab. Proc Natl Acad Sci USA 117: 10970-10975, 2020.

109. Taylor PC, Keystone EC, van der Heijde D, Weinblatt ME, del Carmen Morales L, Reyes Gonzaga J, Yakushin S, Ishii T, Emoto K, Beattie S, et al: Baricitinib versus Placebo or Adalimumab in Rheumatoid Arthritis. N Engl J Med 376: 652-662, 2017

110. Bronte V, Ugel S, Tinazzi E, Vella $A$, De Sanctis F, Canè $S$, Batani V, Trovato R, Fiore A, Petrova V, et al: Baricitinib restrains the immune dysregulation in severe COVID-19 patients. J Clin Invest: 141772, 2020. Doi: 10.1172/JCI141772. (Online ahead of print)

111. Stebbing J, Phelan A, Griffin I, Tucker C, Oechsle O, Smith D and Richardson P: COVID-19: Combining antiviral and anti-inflammatory treatments. Lancet Infect Dis 20: 400-402, 2020 .

112.Jorgensen SCJ, Ly Tse C, Burry L and Dresser LD: Baricitinib: A review of pharmacology, safety and emerging clinical experience in COVID-19. Pharmacotherapy 40: 843-856, 2020

113. Richardson P, Griffin I, Tucker C, Smith D, Oechsle O, Phelan A, Rawling M, Savory E and Stebbing J: Baricitinib as potential treatment for $2019-\mathrm{nCoV}$ acute respiratory disease. Lancet 395 : e30-e31, 2020

114. Cantini F, Niccoli L, Matarrese D, Nicastri E, Stobbione P and Goletti D: Baricitinib therapy in COVID-19: A pilot study on safety and clinical impact. J Infect 81: 318-356, 2020.

115. National Institute of Allergy and Infectious Diseases: Adaptive COVID-19 Treatment Trial 2. ClinicalTrials.gov Identifier: NCT04401579. https://clinicaltrials.gov/ct2/show/NCT044015 79? cond $=$ ACTT $-2 \&$ draw $=2 \&$ rank $=1$. Last Updated August 13 , 2020 .

116. National Institute of Allergy and Infectious Diseases: Adaptive COVID-19 treatment trial (ACTT). ClinicalTrials. gov Identifier: NCT04280705. https://clinicaltrials. gov/ct2/show/study/NCT04280705.

117. Wu R, Wang L, Kuo HD, Shannar A, Peter R, Chou PJ, Li S, Hudlikar R, Liu X, Liu Z, et al: An update on current therapeutic drugs treating COVID-19. Curr Pharmacol Rep: 1-15, 2020.

118. Roback JD and Guarner J: Convalescent plasma to treat COVID-19: Possibilities and challenges. JAMA 323: 1561-1562, 2020

119. Shen C, Wang Z, Zhao F, Yang Y, Li J, Yuan J, Wang F, Li D, Yang M, Xing L, et al: Treatment of 5 critically ill patients with COVID-19 with convalescent plasma. JAMA 323: 1582-1589, 2020.

120. Xia X, Li K, Wu L, Wang Z, Zhu M, Huang B, Li J, Wang Z, $\mathrm{Wu} \mathrm{W}, \mathrm{Wu} \mathrm{M}$, et al: Improved clinical symptoms and mortality among patients with severe or critical COVID-19 after convalescent plasma transfusion. Blood 136: 755-759, 2020.

121. Hegerova L, Gooley TA, Sweerus KA, Maree C, Bailey N, Bailey M, Dunleavy V, Patel K, Alcorn K, Haley R, et al: Use of convalescent plasma in hospitalized patients with Covid-19: Case series. Blood 136: 759-762, 2020 
122. Duan K, Liu B, Li C, Zhang H, Yu T, Qu J, Zhou M, Chen L, Meng S, Hu Y, et al: Effectiveness of convalescent plasma therapy in severe COVID-19 patients. Proc Natl Acad Sci USA 117: 9490-9496, 2020.

123. Li L, Zhang W, Hu Y, Tong X, Zheng S, Yang J, Kong Y, Ren L, Wei Q, Mei H, et al: Effect of convalescent plasma therapy on time to clinical improvement in patients with severe and life-threatening COVID-19: A randomized clinical trial. JAMA 324: 460-470, 2020.

124. Sharpe HR, Gilbride C, Allen E, Belij-Rammerstorfer S, Bissett C, Ewer K and Lambe T: The early landscape of coronavirus disease 2019 vaccine development in the UK and rest of the world. Immunology 160: 223-232, 2020.

125. Callaway E: The race for coronavirus vaccines: A graphical guide. Nature 580: 576-577, 2020.

126. Gao Q, Bao L, Mao H, Wang L, Xu K, Yang M, Li Y, Zhu L, Wang N, Lv Z, et al: Development of an inactivated vaccine candidate for SARS-CoV-2. Science 369: 77-81, 2020.
127. Wang H, Zhang Y, Huang B, Deng W, Quan Y, Wang W, Xu W, Zhao Y, Li N, Zhang J, et al: Development of an inactivated vaccine candidate, BBIBP-CorV, with potent protection against SARS-CoV-2. Cell 182: 713-721.e9, 2020.

128. Zhu FC, Li YH, Guan XH, Hou LH, Wang WJ, Li JX, Wu SP, Wang BS, Wang Z, Wang L, et al: Safety, tolerability, and immunogenicity of a recombinant adenovirus type-5 vectored COVID-19 vaccine: A dose-escalation, open-label, non-randomised, first-in-human trial. Lancet 395: 1845-1854, 2020.

This work is licensed under a Creative Commons Attribution-NonCommercial-NoDerivatives 4.0 International (CC BY-NC-ND 4.0) License. 